\title{
THE SEASONAL VARIATION IN THE COPPER CONTENT OF SEA WATER
}

\author{
By W. R. G. Atkins, F.R.I.C., F.R.S. \\ The Plymouth Laboratory
}

(Text-fig. I)

In previous papers $(1932,1933)$ the author showed that sea water taken from the English Channel contained about ro $\mathrm{mg} . / \mathrm{m}^{3}$ of copper, and obtained agreement between electro-deposition with subsequent colorimetric analysis and colorimetric analysis carried out on sea water concentrated to one-fifth of its volume. For extraction of the copper complex, carbon tetrachloride was found to be the most convenient solvent. The changes throughout the year have, however, only recently been determined. It is of interest to see that water from Station E I, surface, taken 23 March I93I, gave Io mg. $/ \mathrm{m} .{ }^{3}$ by direct colorimetry and 9.7 with electro-deposition, whereas the extraction method curves for 1948 and 1949, read off for the same date, showed respectively $9 \cdot 4$ and II.4 $\mathrm{mg}$. $/ \mathrm{m} .^{3}$.

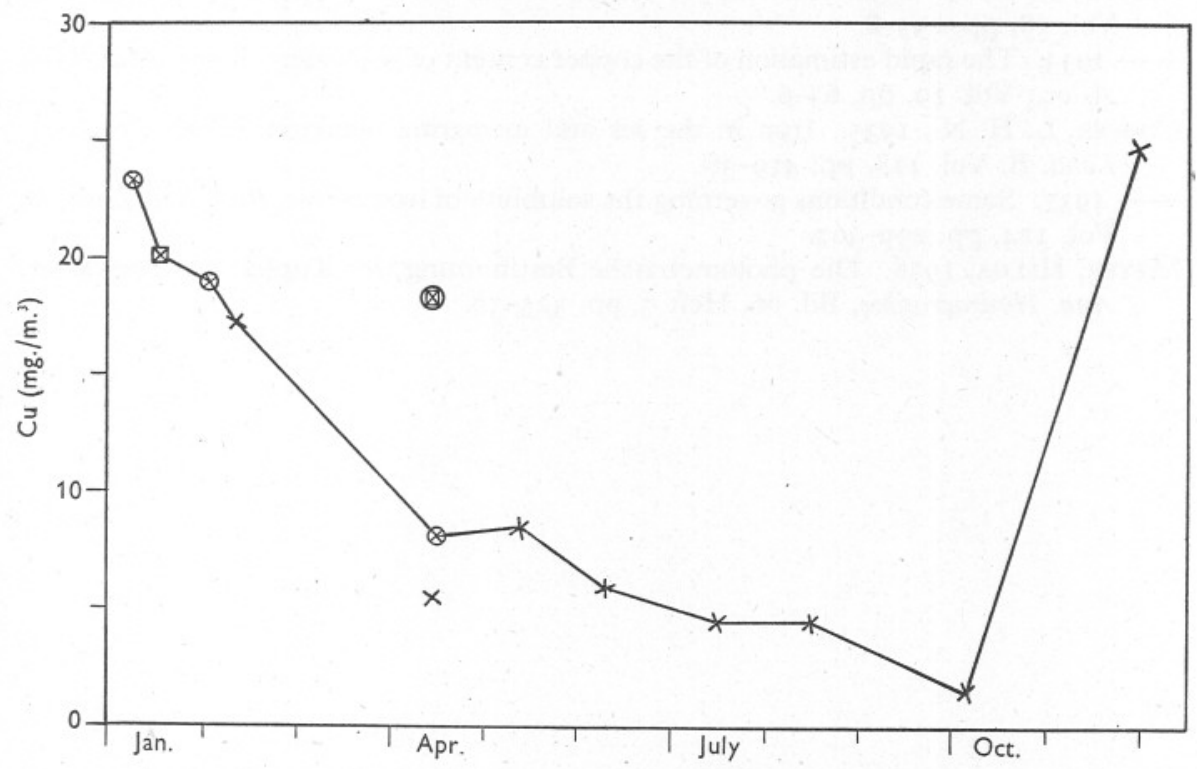

Fig. I. The abscissae show months, the ordinates copper in milligrams per cubic metre of sea water. Results for surface water at International Hydrographic Station E I ( $50^{\circ} \mathrm{O} 2^{\prime} \mathrm{N}$., $04^{\circ} 22^{\prime}$ W.) are denoted by crosses for 1948 , crosses in circle for 1949 - with one in a circle and a square also for $50 \mathrm{~m}$., and by a cross in a square for 1950, one only, in January. 
Early attempts to examine deep water were given up on account of the solubility of the metal bottle, but in I949 a plastic-lined bottle was temporarily satisfactory and, on I3 April, $50 \mathrm{~m}$. gave $18.3 \mathrm{mg}$. Cu as against $8 . \mathrm{I}$ for the surface, sampled with a wooden bucket. Copper is thus a minor constituent which is taken up by the phytoplankton. The results for the surface water during 1948 and 1949, together with one observation for January 1950, have been combined in a single curve, as shown in Fig. I, in which, after an autumn minimum of $\mathrm{r} .5 \mathrm{mg}$. $/ \mathrm{m}^{3}$, a winter maximum 24.8 is reached. The colour given by the high values was a rather browner tint than expected, so presence of iron was suspected. It had, however, been shown in the 1932 paper that it required I. $32 \mathrm{mg}$./1. ferric iron to equal in depth of colour 0.0I mg./1. copper. Moreover, Cooper (1935, 1937) showed that no more than $2 \cdot 2 \mathrm{mg}$./1. ferrous iron could remain in solution in sea water and that the amount as ferric in solution was far beyond colorimetric detection. Ferrous iron could thus have introduced no serious error in the copper analyses. Miscellaneous analyses by Meyer (1938) showed 6-15.5 mg. $/ \mathrm{m}^{3}$ copper in the Baltic, $9-26 \mathrm{mg} . / \mathrm{m}^{3}$ in Kiel harbour, Io $\mathrm{mg} . / \mathrm{m}^{3}$ in the North Sea, 8 -II mg. $/ \mathrm{m}^{3}$ in the Bay of Biscay, with $\mathrm{I} 2 \mathrm{mg} . / \mathrm{m}^{3}{ }^{3}$ in the Canary Stream.

\section{REFERENCES}

Atkins, W. R. G., I932. The copper content of sea water. Fourn. Mar. Biol. Assoc., Vol. I8, pp. 193-8.

- 1933. The rapid estimation of the copper content of sea water. Fourn. Mar. Biol. Assoc., Vol. 19, pp. 63-6.

Cooper, L. H. N., I935. Iron in the sea and in marine plankton. Proc. Roy. Soc. Lond. B, Vol. II 8, pp. 419-38.

- 1937. Some conditions governing the solubility of iron. Proc. Roy. Soc. Lond. B, Vol. 124, pp. 299-307.

MeYer, HelGA, I938. Die photometrische Bestimmung des Kupfers im Seewasser. Ann. Hydrographie, Bd. 66, Heft 7, pp. 325-30. 